\title{
MORPHOLOGICAL CHARACTERIZATION AND PROPERTIES OF CATTAIL FIBERS
}

\author{
MORFOLOŠKA KARAKTERIZACIJA IN LASTNOSTI ROGOZNIH \\ VLAKEN
}

\author{
Jing Zhang1, Xiaofei Yan², Shengbin Cao ${ }^{1 *}$, Guangbiao $\mathrm{Xu}^{3,4}$ \\ ${ }^{1}$ Shanghai Dianji University, Institute of Materials Science, Shanghai 201306, China \\ ${ }^{2}$ Kyoto Institute of Technology, Department of Biobased Materials, Kyoto 606-8585, Japan \\ ${ }^{3}$ Donghua University, College of Textiles, Shanghai 201620, China \\ ${ }^{4}$ Donghua University, Ministry of Education, Key Laboratory of Textile Science and Technology, Shanghai 201620, China \\ *caosb@sdju.edu.cn
}

Prejem rokopisa - received: 2018-04-03; sprejem za objavo - accepted for publication: 2018-05-10

doi:10.17222/mit.2018.062

\begin{abstract}
To extend the applications of cattail fibers in the textile, engineering and apparel industry, the morphological structure and properties of cattail fibers were tested and analyzed. The morphology was examined with a scanning electron microscope (SEM) and an optical microscope. The results show that the cross-sections of the cattail fibers were in the shapes of " $\pi$ " or "Y" or " $><$; the fiber length and fineness were mainly in ranges of $2.25-10.65 \mathrm{~mm}$ and $10-15 \mu \mathrm{m}$, respectively; there were about 56 fibers in a cattail cluster. The moisture-regain rate and mass ratio of the resistor of cattail fibers were measured to be $7.57 \%$ and $1012.5 \Omega \cdot \mathrm{g} / \mathrm{cm}^{2}$. In this case, the composition of the cattail fiber was similar to that of the kapok fiber. In addition, its $\mathrm{pH}$ value was found to be 6.7 , which is harmless to the human body and the pectin content of the cattail fibers was found to be $1.013 \%$, which is similar to the cotton fibers. Furthermore, the acid resistance of the cattail fibers is better than their alkali resistance.

Keywords: cattail fiber, morphological structure, properties

Avtorji prispevka so testirali in analizirali morfološko strukturo in lastnosti rogoznih vlaken, da bi razširili njihovo uporabo v tekstilni industriji in inženirstvu. Morfologijo vlaken so analizirali pod optičnim in vrstičnim elektronskim mikroskopom (SEM; angl.: Scanning Electron Microscope). Raziskave so pokazale, da so vlakna v preseku različnih oblik: " $\pi$ "," Y " ali "><"; dolžina vlaken je bila večinoma med $2,25 \mathrm{~mm}$ in $10,65 \mathrm{~mm}$ in debelina (premer) med $10 \mu \mathrm{m}$ in $15 \mu \mathrm{m}$. V vsakem rogoznem svitku (stroku) je okoli 56 vlaken. Vsak strok se navlaži s približno 7,57 \% vode in ima specifično električno upornost pribl. $1012,5 \Omega \cdot \mathrm{g} / \mathrm{cm}^{2}$. Sestava njihovih vzorcev je bila podobna sestavi vlaken kapokovca. Poleg tega imajo vlakna pH vrednost 6,7 , kar je neškodljivo za človeško telo. Izmerjena vsebnost pektina v rogoznih vlaknih je bila 1,013\%, kar je podobno kot v vlaknih bombaža. Nadalje avtorji ugotavljajo, da je odpornost vlaken proti kislinam boljša kot njihova odpornost proti bazam.

Ključne besede: rogozna vlakna, morfološka struktura, lastnosti
\end{abstract}

\section{INTRODUCTION}

Cattail is also called typhalatifolia, calceolaria, wild candle, typhaangustifolia, etc. ${ }^{1}$ The genus is largely distributed in the northern hemisphere where it is found in a variety of wetland habitats. In "Compendium of Materia Medica", there are some records on the cattail. They show that cattail functions as a sedative and tranquilizer, clearing internal heat and cooling the blood, which is good for children and adults. ${ }^{2}$ As a natural plant fiber, cattail fiber is abundant, cheaper, biodegradable and environment-friendly. ${ }^{3-4}$ Due to the disadvantages of being short, light, hard to collect, easily broken, etc., cattail fibers are not effectively and fully used which leads to a waste of the resources..$^{5-6}$ The morphological characteristics and basic properties of the fibers play important roles in their utilization, ${ }^{7}$ i.e., the morphological characteristics directly determine the essential application aspect of a textile fiber, and the basic properties directly determine the processing and staining method of the fiber.
At present, most research works in engineering relating to cattail fibers focus on oil absorption using the water-proof and oil-absorption characteristics of the wax attached to the surface of the cattail fiber. ${ }^{8-14}$ However, the research on the aspects of textile and clothing, especially on the morphological characterization and basic properties is rare.

This research not only focused on the cattail fiber's morphological characterization, including the fiber length, the fiber number contained in a cluster, the fiber fineness, etc., but also investigated the essential properties such as specific resistance, moisture regain, acid and alkali resistance, $\mathrm{pH}$ and pectin content. All the findings can provide a more solid theoretical basis for an exploitation and utilization of the cattail fiber in the field of textile and clothing.

\section{EXPERIMENTAL PART}

\subsection{Materials}

The raw material of cattail fibers was collected from a lake in the Songjiang district, Shanghai City, China. 


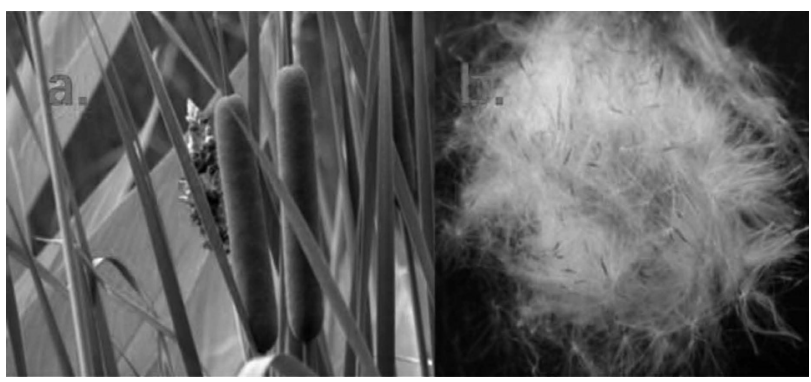

Figure 1: Images of cattail and cattail fibers (a: cattail; b: cattail fibers)

The fibers for testing were from mature plants, whose spikes naturally burst as shown in Figure 1.

\subsection{Morphological characterization}

\subsubsection{Morphological structure}

Cattail fibers were observed with a video microscope (KH-1000 3D, Hirox-USA, Inc., USA), ordinary optical microscope (CXR2, Labomed, USA), and scanning electron microscope (SEM) (DXS-10A, TM3000, Hitachi, Japan).

\subsubsection{Cattail-fiber length}

The millimeter scale, tweezers and a blackboard were used for measuring the cattail-fiber length. With the tweezers, some cattail fibers from the end and middle parts of the spike of a cattail were placed on the blackboard, measured on the millimeter scale one by one, and their length values were recorded separately. A group of fibers was used to analyze the fiber length, and the mid-value was taken as the average length. Then, the fiber with a spacing of $0.3 \mathrm{~mm}$ was sub-filed. The standard deviation and coefficient of variation $(\mathrm{CV} \%)$ were used for describing the fiber-length dispersion status as shown in Equations (1) and (2):

$$
\begin{gathered}
S=\sqrt{\frac{\sum f(X-\bar{X})^{2}}{n-1}}=\sqrt{\frac{\sum f d^{\prime 2}-\frac{\sum f d^{\prime 2}}{n}}{n-1}} \times i \\
C V \%=\frac{S}{\bar{X}} \times 100 \%
\end{gathered}
$$

where $S$ is the standard deviation; $X$ is the value of each fiber from the group; $\bar{X}$ is the average value of each group; $f$ is the number of the measured fibers; $i$ is the group spacing; $d$ ' is the assumed square set distance; $n$ is the total fiber number.

\subsubsection{Cattail-fiber fineness}

The shape of the cattail fiber is not a single tubule but a bifurcated structure. Several bifurcated fibers gather into a cattail cluster. Thus, fiber fineness is defined as the average fineness of the cattail fibers in a cattail cluster. An optical microscope (CXR2, Labomed, USA) was used for the fineness observation and the fineness of cattail fibers was tested in accordance with GB/T10685-
1989 Wool - Determination of fiber diameter - Projection microscope method.

\subsubsection{Cattail's single fiber in a cluster}

A fiber cluster was removed from a mature spike of cattail and cut through its tail section; then the fibers were distributed on the blackboard. By counting the cattail fibers, the number of the fibers contained in the cluster was determined. We used the video microscope (KH-1000 3D, Hirox-USA, Inc., USA) to observe the cattail fibers.

\subsection{Properties}

\subsubsection{Moisture-regain and specific-electrical-resistance tests of cattail fibers}

We tested the moisture-regain rate for the cattail spike in the standard state according to GB/T 9995-1997 Determination of the moisture content and moisture regain of textile - Oven-drying method.

A 50-g fiber sample was obtained and kept under the standard atmospheric condition for more than 4 hours (a temperature of $20{ }^{\circ} \mathrm{C} \pm 2{ }^{\circ} \mathrm{C}$, relative humidity of $65 \% \pm 2 \%$ ). A sample with a weight of $15 \mathrm{~g}$ was weighted with an electric balance (Mitsubishi Co., Ltd., Japan, 0.01g). Then we tested their resistance with a YG321 specificelectrical-resistance tester. Three parallel experiments were set up to ensure the accuracy of the results.

\subsubsection{Infrared-spectroscopy analysis}

According to the characteristic absorption peaks in the infrared spectrogram, we could recognize the chemical bond of the fiber and identify the main ingredients in the cattail fiber using a USA Nicolet 5700 infrared spectrometer.

\subsection{3 $\mathrm{pH}$ test}

The $\mathrm{pH}$ of the cattail fiber and kapok fiber was measured and analyzed in accordance with GB/T 7573 Textiles - Determination of $\mathrm{pH}$ of an aqueous extract.

\subsubsection{Analysis of the acid and alkali resistance of cattail fibers}

We had 50 fiber samples of $1 \mathrm{~g}$. We used water for the solutions with different concentrations of $\mathrm{H}_{2} \mathrm{SO}_{4}$ and $\mathrm{NaOH}$ where the concentration gradient was $5 \%$. Then we put the fibers into different solutions for one hour, washed them 3 to 4 times with distilled water, naturally air dried them and observed the changes of the fibers and solutions. We used $\mathrm{CH}_{3} \mathrm{CH}_{2} \mathrm{OH}$ as the solvent to obtain different degrees of the $\mathrm{H}_{2} \mathrm{SO}_{4}$ concentration. $\mathrm{CH}_{3} \mathrm{CH}_{2} \mathrm{OH}$ was used because cattail fibers can be completely infiltrated in $\mathrm{CH}_{3} \mathrm{CH}_{2} \mathrm{OH}$, but not in water. Then we observed the change in the acid-resistance properties of the solutions with different $\mathrm{H}_{2} \mathrm{SO}_{4}$ concentrations in the same experiment conditions. The experiment processes and conditions for $\mathrm{NaOH}$ were the same as those for $\mathrm{H}_{2} \mathrm{SO}_{4}$. 


\subsubsection{Pectin in cattail fibers}

Using the carbazole chromogenic method to determine the pectin content in the cattail fibers, the standard curve of the pectin concentration/absorbance was first drawn. A 2-mL amount of pectin with a mass fraction of $0.25 \%$ was diluted in $50 \mathrm{~mL}$ of water. Then, we marked 13 pieces of tubes and filled them separately with $6 \mathrm{~mL}$ of $\mathrm{H}_{2} \mathrm{SO}_{4}$. We injected different volumes of pectin and water into the tubes and cooled the tubes down by putting them into an ice-water bath. After the cooling, we put them into a boiling-water bath for $15 \mathrm{~min}$ and then cooled them down again. We injected $1 \mathrm{~mL}$ of 0.15 $\%$ carbazole anhydrous ethanol and put the samples into an $85{ }^{\circ} \mathrm{C}$ water bath for $30 \mathrm{~min}$ to keep the color. Then we took them out and cooled them down. We tested the absorbance at $535 \mathrm{~nm}$ and drew the carbazole pectin standard curve, determining the absorbance at $535 \mathrm{~nm}$ with vertical coordinates, as shown in Figure 2. If the pectin content is $x$ and the tested absorption of the cattail fiber is $A$, the calculation of pectin is made with Equation (3):

$$
X=\frac{A}{136.305} \times 100 \%
$$

\section{RESULTS AND DISCUSSION}

\subsection{Morphological characterization}

\subsubsection{Morphological structure}

Morphological structure of cattail fibers is shown in Figure 3. It is very similar to the shape of eiderdown or a flower. There are three parts of the structure: the cattail seed, the single fiber and the cattail-fiber stem. Between the stem root and the top, there are several single fibers in the middle part and the part called the root. There are about 40 to 50 single fibers in the first root. There are fewer than 3 roots in the cattail-fiber stem. As shown on Figure 3c, the longitudinal surface of the cattail fiber is not smooth as there are several points on the single fiber that are similar to bamboo; these points stick out significantly so that the surface of the single fiber is not smooth. However, the surface is smooth between these points. As there are many such points, the diameter of

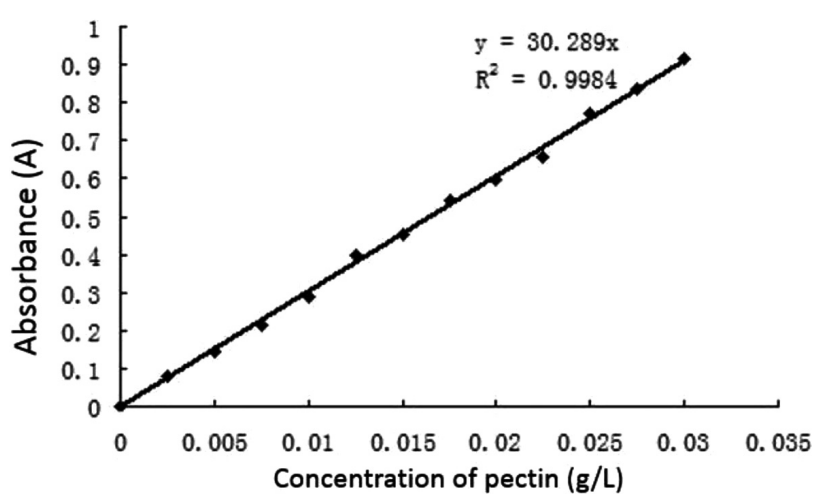

Figure 2: Carbazole pectin standard curve
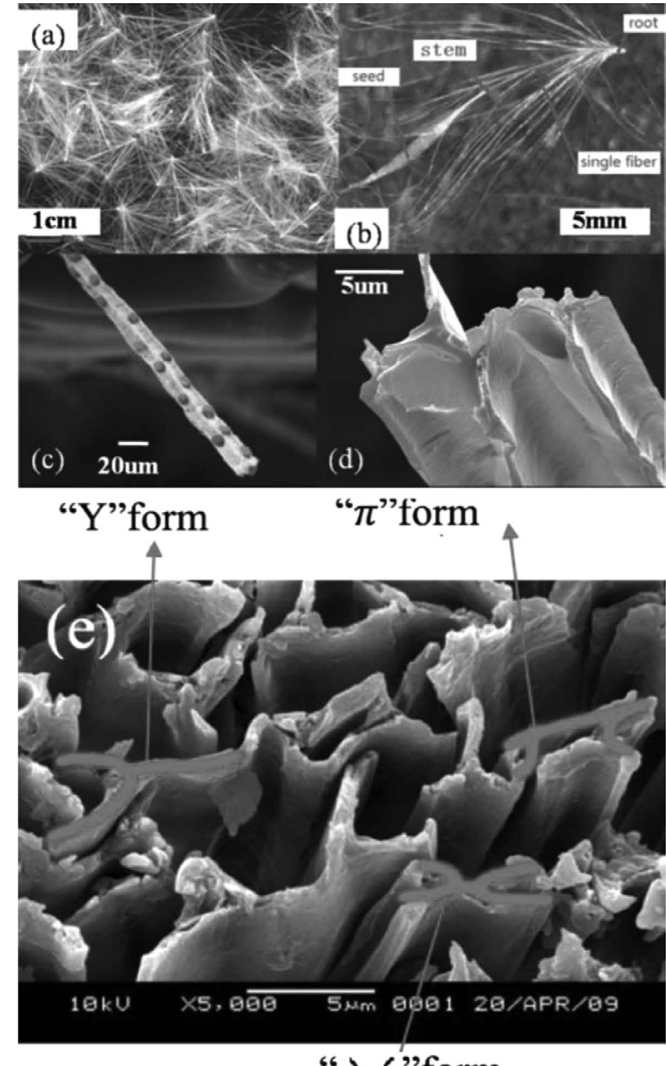

") - "form

Figure 3: Morphological structure of cattail fibers

the cattail fiber is not uniform. Figure 3e shows that the cross-sections of cattail fibers exhibit a special $\pi$ form or $\mathrm{Y}$ form or $><$ form. The special structure of cattail fibers allow the fibers to keep a large quantity of silent air

\subsubsection{Cattail-fiber length}

All parts of a cattail-fiber length are shown in Figure 4. It can be observed that the length of the terminal part

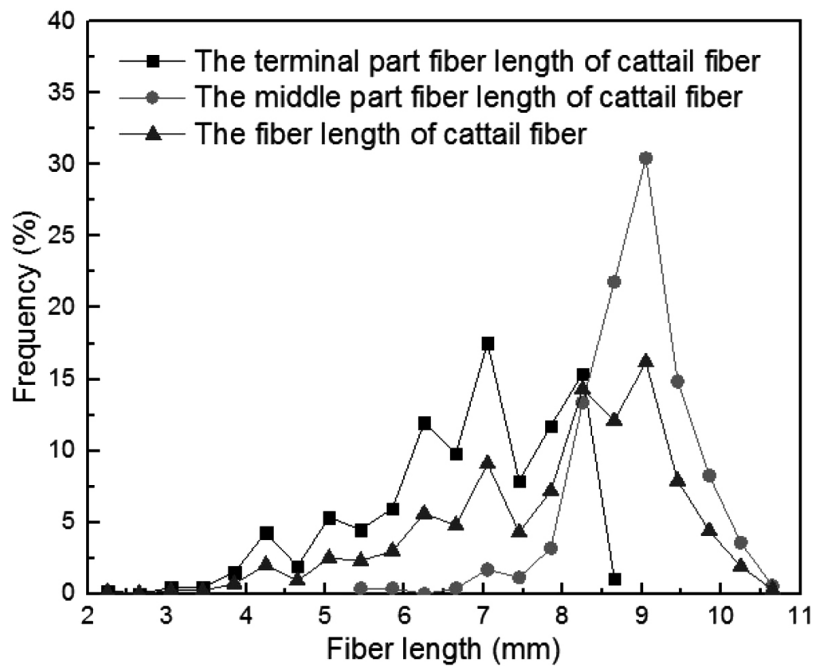

Figure 4: Cattail-fiber-length probability density distribution 
of the cattail fiber is in a range of $2.25-8.65 \mathrm{~mm}$, and the concentrated-distribution length is in a range of $6.25-8.25 \mathrm{~mm}$. The first half of the curve is gentle, while the rest is quite steep. In addition, the end spike of the cattail is distributed dispersedly and its average length is $6.7 \mathrm{~mm}$. However, the length of the middle part of the cattail fiber is concentrated from $5.45 \mathrm{~mm}$ to $10.65 \mathrm{~mm}$. At $8.25-9.85 \mathrm{~mm}$, the fibers exhibit a concentrated distribution and the curve has an approximately normal distribution. The average length is $8.90 \mathrm{~mm}$. Meanwhile, the length distribution of the end spike of the cattail impacts the whole length dispersion. Above all, the cattail fiber can be distributed at the length of 2.25-10.65 $\mathrm{mm}$ and the curve exhibits an approximately normal distribution at the length of $6.25-9.85 \mathrm{~mm}$. In general, the length distribution for the cattail fiber is dispersive and its average length is $7.9 \mathrm{~mm}$.

\subsubsection{Cattail-fiber fineness}

On Figure 5, it can be observed that the fineness of the terminal part of the cattail fiber ranged from $10 \mu \mathrm{m}$ to $22.5 \mu \mathrm{m}$; there were mainly two distribution sections, $10 \mu \mathrm{m}$ to $12.5 \mu \mathrm{m}$ and $12.5 \mu \mathrm{m}$ to $15 \mu \mathrm{m}$, which was a large dispersion and the fiber exhibited a scattering distribution. The fineness of the middle part of the cattail fiber was different from $10 \mu \mathrm{m}$ to $27.5 \mu \mathrm{m}$, and the fineness of the fiber was mainly divided into three sections: $10 \mu \mathrm{m}$ to $12.5 \mu \mathrm{m}, 12.5 \mu \mathrm{m}$ to $15 \mu \mathrm{m}$ and $15 \mu \mathrm{m}$ to $17.5 \mu \mathrm{m}$. The dispersion was larger than for the terminal fiber of the cattail stick. The total fineness of the cattail fiber ranged from $10 \mu \mathrm{m}$ to $27.5 \mu \mathrm{m}$ and it was mainly divided into three sections: $10-12.5 \mu \mathrm{m}, 12.5-15$ $\mu \mathrm{m}$ and $15-17.5 \mu \mathrm{m}$. The average fineness of the terminal fibers was $13.35 \mu \mathrm{m}$ and the fibers were also very dispersive. The total fineness distribution of the cattail fibers was mainly influenced by the middle-section fibers. The total fineness of the cattail fibers was mainly divided into two sections, $10 \mu \mathrm{m}$ to $12.5 \mu \mathrm{m}$ and $12.5 \mu \mathrm{m}$ to $15 \mu \mathrm{m}$, and $52 \%$ of the terminal cattail fibers were in

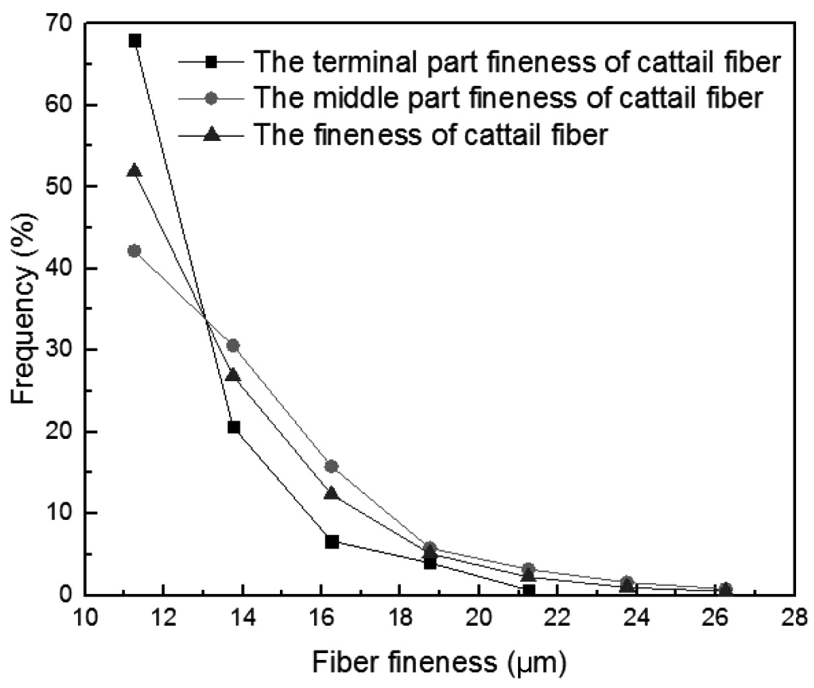

Figure 5: Cattail-fiber-fineness probability density distribution a range of 10-12.5 $\mu \mathrm{m}$, being more concentrated and thinner than the middle-section cattail fibers. The distribution of the middle-section cattail fibers was more dispersive and the fineness was bigger.

\subsubsection{Cattail's single fibers in a cluster}

Distribution of single fibers in the cattail is shown in Figure 6. A piece of cattail contains about 30-80 single fibers. The average number of single fibers in a cluster is 56. It can be seen that the distribution of the single fibers contained in one cattail cluster is random.

\subsection{Properties}

\subsubsection{Moisture-regain and specific-resistance test for the cattail spike and cattail fiber}

The moisture regain of the cattail spike was $4.78 \%$ under the atmospheric static condition, while the moisture regain of the cattail fiber was $7.57 \%$. The fibers were closely packed in the cattail spike, which was bad for the water absorption and release. Therefore, the moisture regain of the cattail fibers was larger than that of the cattail spike but smaller than that of the cellulose fibers, which have a higher water-absorption ability. ${ }^{15}$

The mass-ratio resistance of the cattail fibers was $1012.5 \Omega \cdot \mathrm{g} / \mathrm{cm}^{2}$, which was smaller than that of the common fibers. ${ }^{15}$ It was difficult for the cattail fibers to build up static electricity so that the influence of static electricity could be ignored.

\subsubsection{Infrared-spectroscopy analysis}

As shown on Figure 7, the results of the infrared spectroscopy of the cattail fibers were very similar to those of the kapok fibers, exhibiting the typical vibration mode of fibrin and hydrocarbon. The widest peak, $3363 \mathrm{~cm}^{-1}$, could be linked to the stretching vibration of anti-free -OH, given that the waxiness of the cattail fibers was very higher. The peaks at $2925.3 \mathrm{~cm}^{-1}$ and $2846.7 \mathrm{~cm}^{-1}$ corresponded to the stretching vibration of

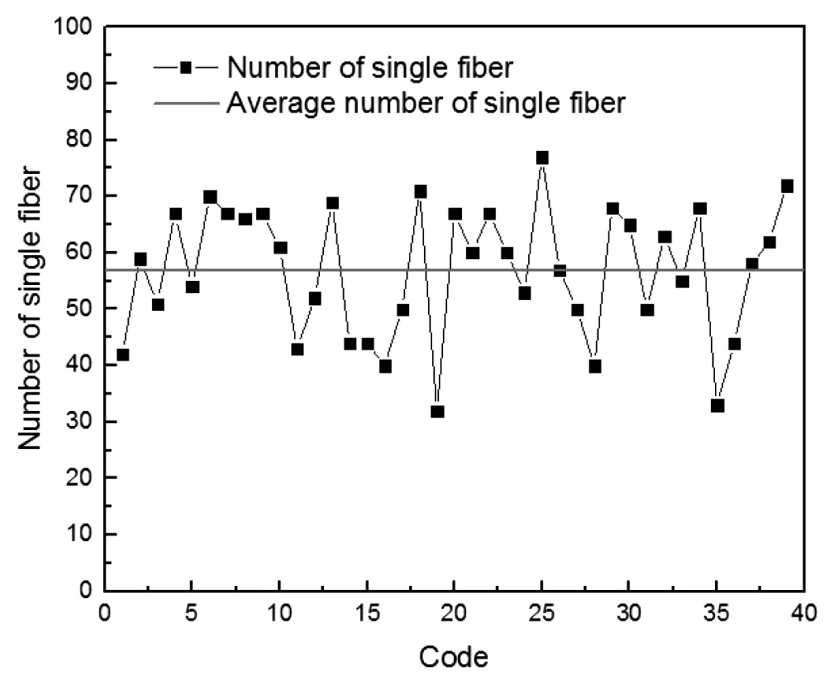

Figure 6: Number of single fibers contained in a cattail cluster 


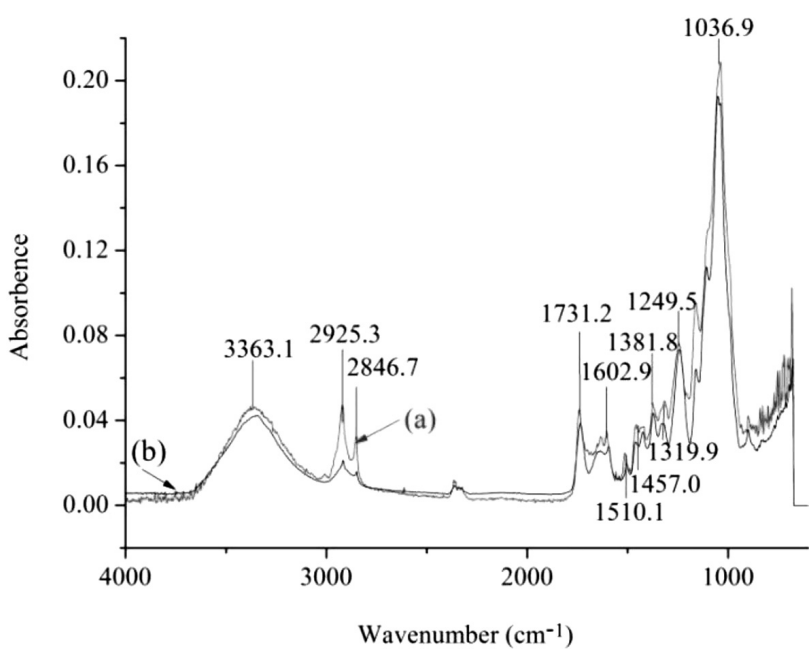

Figure 7: Infrared spectra of: a) cattail fibers, b) kapok fibers

$\mathrm{CH}_{2}$ and $\mathrm{CH}_{3}$ and were related to the existence of the vegetable wax. ${ }^{16}$ These two obvious heavy-vibration peaks show that the waxiness was very high. According to a report, ${ }^{17}$ the waxiness of cattail fibers was $10.64 \%$, which was much higher than those of the kapok fibers and cotton fibers. The absorption band was caused by the stretching vibration of $\mathrm{C}=\mathrm{O}$, which existed in ketone, carboxyl, ester and xylan of $1731.2 \mathrm{~cm}^{-1}, 1381.8 \mathrm{~cm}^{-1}$ and $1249.5 \mathrm{~cm}^{-1}$ lignose. There were three more obvious peaks near $1602.9 \mathrm{~cm}^{-1}, 1510.1 \mathrm{~cm}^{-1}$ and $1457.0 \mathrm{~cm}^{-1}$, connected with the stretching vibration of $\mathrm{C}=\mathrm{O}$ and $\mathrm{C}=\mathrm{C}$ in lignin. ${ }^{18}$ The peak value at $1036.9 \mathrm{~cm}^{-1}$ of the strongest band showed the stretching vibration of $\mathrm{C}-\mathrm{O}$ in cellulose, hemicelluloses and lignose, all indicating that the cattail fiber is a kind of cellulose fiber. ${ }^{19}$

\subsection{3 $\mathrm{pH}$ test of cattail fibers}

Taking the average $\mathrm{pH}$ value of the cattail-fiber water extraction as the test data involved a $\mathrm{pH}$ precision of 0.1 . After the test, the $\mathrm{pH}$ value of the cattail fiber was 6.7, which conformed to the standard product $\mathrm{pH}$ value required by GB18401. It is harmless for direct human touch so this $\mathrm{pH}$ is safe and comfortable for the human body.

\subsubsection{Analysis of the acid resistance and alkali resist- ance of cattail fibers}

The cattail fibers were kept in solutions for one hour as shown in Table 1. Then, they were taken out and dried. The obtained results for the cattail fibers from different acid or alkali solutions are presented in Figure 8.

The color and morphological changes of A11 to A16 were not obvious, but the colors of A17, A18 and A19 all changed immediately from sepia to black; the shape changed from fiber into powder. These phenomena indicated that proportions of $0 \%$ to $45 \%$ of $\mathrm{H}_{2} \mathrm{SO}_{4}$ make no obvious damage to the fibers, but when the level of $\mathrm{H}_{2} \mathrm{SO}_{4}$ is above $45 \%$, obvious damage is made to the fibers; and when the level of $\mathrm{H}_{2} \mathrm{SO}_{4}$ reaches $65 \%$, the fibers become carbonized and finally change into powder, which means that the molecular structure of the fibers is also changed.

Table 1: Ratios of different solutions

\begin{tabular}{|c|c|c|c|}
\hline $\begin{array}{c}\text { Code } \\
\%\end{array}$ & $\begin{array}{c}\mathrm{A} 1 \\
\mathrm{H}_{2} \mathrm{SO}_{4} / \mathrm{H}_{2} \mathrm{O}\end{array}$ & $\begin{array}{c}\mathrm{A} 2 \\
\mathrm{NaOH} / \mathrm{H}_{2} \mathrm{O}\end{array}$ & $\begin{array}{c}\mathrm{A} 3 \\
\mathrm{H}_{2} \mathrm{SO}_{4} / \mathrm{C}_{2} \mathrm{H}_{5} \mathrm{OH}\end{array}$ \\
\hline 1 & $0 / 100$ & $0 / 100$ & $5 / 95$ \\
\hline 2 & $5 / 95$ & $5 / 95$ & $10 / 90$ \\
\hline 3 & $15 / 85$ & $10 / 90$ & $15 / 85$ \\
\hline 4 & $25 / 75$ & $15 / 85$ & $20 / 80$ \\
\hline 5 & $35 / 65$ & $20 / 80$ & $25 / 75$ \\
\hline 6 & $45 / 55$ & - & $30 / 70$ \\
\hline 7 & $55 / 45$ & - & $35 / 65$ \\
\hline 8 & $60 / 40$ & - & $40 / 60$ \\
\hline 9 & $65 / 35$ & - & $45 / 55$ \\
\hline 10 & - & - & $50 / 50$ \\
\hline 11 & - & - & $55 / 45$ \\
\hline 12 & - & - & $60 / 40$ \\
\hline
\end{tabular}

Not only the color but also the morphology of A21 to A25 was changed obviously. The cattail fibers changed from being fluffy to tight and finally they became powder; the color changed from yellow to sepia. Analyzing these phenomena, we find that when the level of $\mathrm{NaOH}$ reaches $20 \%$, the fibers become powder; but once the level exceeds $20 \%$, the fibers are completely dissolved and the color of the solution becomes blood red.

The morphology and color of A31 to A34 were changed to a smaller degree. However, the color of A35

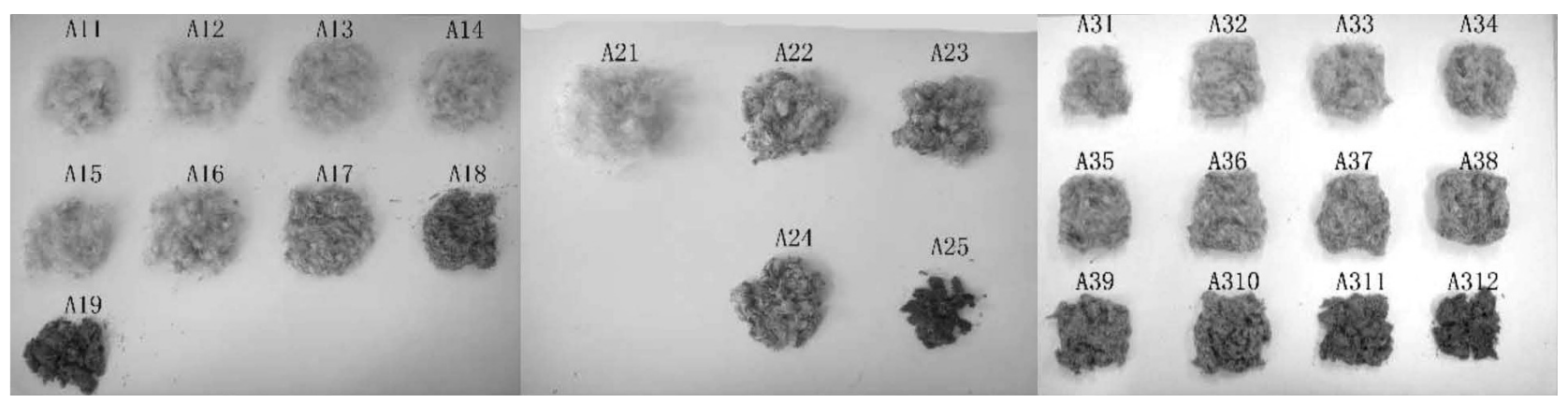

Figure 8: Obtained results for cattail fibers in different acid or alkali solutions 
to A310 changed from sepia to black. The color of A311 and A312 became black and morphologically the fibers changed into powder, similar to A19, as illustrated in Figure 8 .

The limiting concentration was $60 \%$; all the fibers were dissolved and the color of the solution was black when this concentration was higher than $60 \%$. Taking water or $\mathrm{CH}_{3} \mathrm{CH}_{2} \mathrm{OH}$ as the solvent, the acid-resistance level showed no obvious change and $65 \%$ of the fibers changed into powder. Taking water or $\mathrm{CH}_{3} \mathrm{CH}_{2} \mathrm{OH}$ as the solvent, the level of acid resistance showed a larger difference as the color of the cattail fibers changed obviously, its value being $55 \%$ when taking water as the solvent and $25 \%$ when taking $\mathrm{CH}_{3} \mathrm{CH}_{2} \mathrm{OH}$ as the solvent.

Taking water as the solvent, the acid-resistance degree of the cattail fibers was higher than the alkali-resistance degree. When a sample changed to powder under the same conditions, the degree of $\mathrm{H} 2 \mathrm{SO} 4$ was $65 \%$, but the degree of $\mathrm{NaOH}$ was $20 \%$.

Applying the infrared-spectrum analysis to A11, A19, A25, after having kept them in a $65 \%$ degree $\mathrm{H}_{2} \mathrm{SO}_{4}$ solution for one hour, it was found that the color of the cattail fiber became black and its shape changed into powder, but the internal molecular structure was not destroyed and the characteristic group was still in place. After having kept the cattail fiber in a $25 \%$ degree $\mathrm{NaOH}$ solution for one hour, not only the color and the shape changed, but also the internal molecular structure changed and the original group was also decomposed. In conclusion, the cattail fiber was acid-resistant but not alkali-resistant.

\subsubsection{Pectin in cattail fibers}

We put a 1.5 -g cattail fiber into a weighing bottle, heated it at $105^{\circ} \mathrm{C}$ to a constant weight, cooled it down, then cut the fiber sample into pieces and put them into a 250-mL three-necked bottle, filled the bottle with a $100-\mathrm{mL} 0.5 \%\left(\mathrm{NH}_{4}\right)_{2} \mathrm{C}_{2} \mathrm{O}_{4}$ solution, making use of reflux condensation. We kept the sample in boiling water for $1.5 \mathrm{~h}$, then took it out using filtering, used a 3-mL solution to transfer it into concentrated $\mathrm{H}_{2} \mathrm{SO}_{4}$ and mixed the solution well. After it cooled down in ice water, we kept it in boiling water for $15 \mathrm{~min}$, took it out and cooled it down again in ice water. After having filled in a $0.15 \%$ carbazole anhydrous ethanol solution and mixed it well, we heated it for $30 \mathrm{~min}$ in a stable $85^{\circ} \mathrm{C}$ temperature solution until it changed its color. We took it out and cooled it down, compared it with the blank solution and analyzed its absorbency with an ultraviolet-visible light spectrophotometer under a 535-nm wavelength. According to the standard curve, we calculated the amount of pectin and reconverted the results into the percentage of the glia content.

The result of the tested absorption of the cattail fiber was 1.381 , so it could be calculated that the pectin mass of the cattail fiber was $1.013 \%$. It was equal to the kapok fiber and cotton fiber.

\section{CONCLUSIONS}

(1) The structure of the cattail fiber was very similar to eiderdown or the flower shape. The single-fiber surface of the cattail fiber was not smooth, and on every single fiber, there were points, which were similar to bamboo; these points were smooth, but they caused the appearance of the single fibers to be uneven. The crosssections of the cattail fibers exhibited the special $\pi$ form or $\mathrm{Y}$ form or $><$ form.

(2) The differences in the length between the two ends of the cattail fiber and its middle part were very large. Comparatively speaking, the two end fibers were very short and significantly scattered, but the length of the middle section of the fiber was more concentrated. In conclusion, the length distribution of the cattail fiber was dispersed. The fineness distribution of the end cattail fiber was more concentrated than the middle-part fiber, and the middle-part fiber was very thin. The middle-part fiber distribution of the cattail stick was more dispersed and the fineness was thicker. The number of fibers in a cattail flower fiber was from 30 to 80 and the average value was 56 . The distribution of fibers in the cattail flower fiber was random within the limits. The moisture regain of the cattail stick was $4.78 \%$, but the moisture regain of the cattail fiber was $7.57 \%$; the moisture regain of the cattail stick was smaller than that of the cattail fiber. The mass ratio of the resistor of the cattail fiber was very small, much smaller than that of a usual fiber.

(3) The contents of the cattail fiber and cotton fiber were similar; they were a kind of cellulose fiber. The $\mathrm{pH}$ value of the cattail fiber was 6.7 ; therefore, it was harmless for a direct human touch. Taking water as the solvent, the acid-resistance level of the cattail fiber was higher than the alkali-resistance level. When the samples changed into powder under the same conditions, the level of $\mathrm{H}_{2} \mathrm{SO}_{4}$ was $65 \%$, but the level of $\mathrm{NaOH}$ was $20 \%$. Thus, we could confirm that the cattail fiber was acid-resistant, not alkali-resistant. The absorption of the cattail fiber was 1.381 , so the pectin content in the cattail fiber was $1.013 \%$, but the pectin content in a usual cotton fiber also was around $1 \%$.

\section{REFERENCES}

${ }^{1}$ A. Revedin, B. Aranguren, R. Becattini, L. Longo, E. Marconi, M. Lippi, N. Skakun, A. Sinitsyn, E. Spiridonova, J. Svoboda, Thirty thousand-year-old evidence of plant food processing, Proceedings of the National Academy of Sciences, 107 (2010) 44, 18815-18819, doi:10.1073/pnas.1006993107

${ }^{2}$ S. Li, Compendium of Materia Medica, China Archives Publishing Press, Beijing, 1996, 80-255

${ }^{3}$ B. Bremer, K. Bremer, M. Chase, M. Fay, J. Reveal, D. Soltis, S. Pamella, P. Stevens, An update of the angiosperm phylogeny group classification for the orders and families of flowering plants: APG III, Bot. J. Linn. Soc., 161 (2009) 2, 105-121, doi:10.1111/j.10958339.2009.00996.x

${ }^{4}$ Y. Cui, G. Xu, Y. Liu, Oil sorption mechanism and capability of cattail fiber assembly, J. Ind. Text., 43 (2014) 3, 330-337, doi: $10.1177 / 1528083712452902$ 
${ }^{5}$ T. Dong, G. Xu, F. Wang, Oil spill cleanup by structured natural sorbents made from cattail fibers, Ind. Crops Prod., 76 (2015), 25-33, doi:10.1016/j.indcrop.2015.06.034

${ }^{6} \mathrm{~S}$. Cao, T. Dong, G. Xu, F. Wang, Cyclic filtration behavior of structured cattail fiber assembly for oils removal from wastewater, Environ. Technol., (2017), 1-8, doi:10.1080/09593330.2017. 1340349

${ }^{7}$ N. Karousis, I. Suarez, C. Ewels, N. Tagmatarchis, Structure, properties, functionalization, and applications of carbon nanohorns, Chem. Rev., 116 (2016) 8, 4850-4883, doi:10.1021/acs.chemrev. 5 b00611

${ }^{8}$ T. Dong, S. Cao, G. Xu, Highly porous oil sorbent based on hollow fibers as the interceptor for oil on static and running water, J. Hazard. Mater., 305 (2016), 1-7, doi:10.1016/j.jhazmat.2015.11.030

${ }^{9}$ Q. Wang, G. Xu, F. Wang, Adsorption property to oil of cattail fiber, Journal of Donghua University, 1 (2010)

${ }^{10} \mathrm{~S}$. Cao, T. Dong, G. Xu, F. Wang, Study on structure and wetting characteristic of cattail fibers as natural materials for oil sorption, Environ. Technol., 37 (2016) 24, 3193-3199, doi:10.1080/09593330. 2016.1181111

${ }^{11}$ H. N. Son, Y. B. Seo, Physical and bio-composite properties of nanocrystalline cellulose from wood, cotton linters, cattail, and red algae, Cellulose, 22 (2015) 3, 1789-1798, doi:10.1007/s10570-015-0633-Z

${ }^{12}$ T. Dong, S. Cao, G. Xu, Highly efficient and recyclable depth filtrating system using structured kapok filters for oil removal and recovery from wastewater, J. Hazard. Mater., 321 (2017), 859-867, doi:10.1016/j.jhazmat.2016.10.005

${ }^{13}$ Q. M. Rahman, L. Wang, B. Zhang, S. Xiu, A. Shahbazi, Green biorefinery of fresh cattail for microalgal culture and ethanol produc- tion, Bioresour. Technol., 185 (2015), 436-440, doi:10.1016/ j.biortech.2015.03.013

${ }^{14}$ E. Khan, S. Khaodhir, P. Rotwiron, Polycyclic aromatic hydrocarbon removal from water by natural fiber sorption, Water Environ. Res., 79 (2007) 8, 901-911, doi:10.2175/106143007X176040

${ }^{15}$ L. Y. Mwaikambo, M. P. Ansell, Chemical modification of hemp, sisal, jute, and kapok fibers by alkalization, J. Appl. Polym. Sci., 84 (2002) 12, 2222-2234, doi:10.1002/app.10460

${ }^{16}$ A. Y. Abdullah, M. M. Muwalla, H. O. Maharmeh, S. K. Matarneh, M. A. A. Ishmais, Effects of strain on performance, and age at slaughter and duration of post-chilling aging on meat quality traits of broiler, Asian-Australas. J. Anim. Sci., 23 (2010) 12, 1645-1656, doi:10.5713/ajas.2010.10045

${ }^{17}$ S. Chelst, B. Delaine-Facey, S. Hull, D. Jordan, V. MonsaintQueeney, M. Patel, A. Thapa, J. Wall, D. Yee, Evaluating the efficacy of cattail (Typha spp.) fiber for oil sorption, DRUM (Digital Repository at the University of Maryland), (2017), doi:10.13016/ M26T0GW45

${ }^{18}$ A. Zitrin, W. Zheng, T. Broadhurst, J. Moustakas, D. Lam, X. Shu, F. E. Bauer, A geometrically supported $\mathrm{z} \sim 10$ candidate multiply imaged by the Hubble Frontier Fields cluster A2744., The Astrophysical Journal Letters, 793 (2014) 1, L12, doi:10.1088/2041-8205/ 793/1/L12

${ }^{19}$ M. Likon, M. Remškar, V. Ducman, F. Švegl, Populus seed fibers as a natural source for production of oil super absorbents, J. Environ. Manage., 114 (2013), 158-167, doi:10.1016/j.jenvman.2012.03.047 